\title{
SENSE OR NONSENSE?: \\ New Zealand Heritage LegisLation in Perspective
}

\author{
GREG VOSSLER \\ Public History ReVIEW, VOL 13, 2006, PP66-85
}

\begin{abstract}
o appreciate the current position that historic heritage assumes in New Zealand and other comparable western societies, ${ }^{1}$ it is important to understand that heritage protection and management largely occurs within a legislative framework established by government. Peter James suggests that the role legislation plays in this process is basically one which 'provides penalties for use against people if they follow a particular course of action' and that the 'powers to impose penalties and the enabling powers which allow governments to disburse monies for conservation purposes are the only real roles of the law in the conservation process'. ${ }^{2}$

This view, however, overlooks a further key role that legislation assumes - the creation of the legal context within which administrative practice is influenced and informed. This is not to say that legislation is always clear in its purpose or easy to interpret. As Michael Pearson and Sharon Sullivan observe, the extent to which heritage related laws, for instance, are effective is largely dependent on 'the quality and comprehensiveness of the legislation, the zeal and wisdom with which it is implemented, and the adequacy of the administrative and technical systems and financial resources supporting it'. ${ }^{3}$ However, in the last two decades we have witnessed the emergence of an interesting dichotomy within many western democracies that has had a pronounced impact on the effectiveness of heritage legislation and its implementation. This dichotomy, David Butts suggests, can be characterised as follows:
\end{abstract}

On the one hand governments generally recognize the importance of cultural identity in creating a sense of community and the importance of preserving heritage as a part of that cultural identity. On the other hand the dominant political philosophy advocates a more confined role for central and local government, privatisation of government enterprises, and reliance on competition in the market place to determine value. Added to this is the 
traditional concept of the rights of the owner of property, particularly rights of landowners, to determine what happens to their property. ${ }^{4}$

Within New Zealand this dichotomy is also evident. Brett Jones notes, for instance, that historically two 'philosophies' appear to have influenced the development of its heritage legislation: the 'first is that it should respect the community's right to protect such places. The second is that it uphold the freedom of the rights of the property owner to do what they [sic] will with their [sic] property'. ${ }^{5}$

It is this latter 'philosophical' position, however, that generally poses the greatest challenge to legislators. As Peter James observes, 'one of the main bodies of public opinion opposed to most conservation legislation is the property owning and developing lobby. There are obvious reasons, on the face of it, for such opposition because it is the business of those who own and develop property to make money from doing so'. ${ }^{6}$ Any legislation that has at its core an objective to protect places of identified heritage value is, on balance, likely to impinge on the rights of private owners. Given the general reluctance of many governments to introduce legislation that interferes with such rights, a precautionary approach is often applied by legislators.

To begin to understand and appreciate how legislation affects or influences the way in which we protect and manage our historic heritage it is important, therefore, to recognise that it is inevitably political in nature and, as a corollary, subject to the excesses and vagaries associated with political processes operating at the national, regional and local levels. Balanced against this, though, is the need to appreciate that heritage legislation, in whatever guise, is still 'an expression of the community's wish for [heritage place] management, and, if properly written or used, is a useful tool'. ${ }^{7}$ With these sentiments in mind this article will focus on some of the principal statutes affecting historic heritage protection and management in New Zealand.

\section{Historic Heritage Protection: The New Zealand Legislative Landscape ${ }^{8}$} The conclusion that can be drawn from a cursory examination of New Zealand's current legislative 'landscape' is that the number of statutes that impact on historic heritage is very limited. Closer inspection, however, reveals quite the contrary. In reality the range of legislation which either directly or indirectly influences the protection and management of historic heritage is extensive, ${ }^{9}$ and includes such obvious examples as the Resource Management Act 1991 (RMA) and Historic Places Act 1993 (HPA) through to somewhat more obscure statutes as the Burial and Cremation Act $1964 .^{10}$ In light of the breadth of this legislation, what follows is an attempt to identify some of the more important legislative signposts to assist the process of reading and negotiating this 'landscape'. 


\section{RESOURCE MANAGEMENT ACT $1991^{11}$}

The RMA, along with the HPA and the Conservation Act 1987 (CA), comprise the 'key legislation by which the Government provides for the protection and management of the historic and cultural heritage of New Zealand'. ${ }^{12}$ The RMA came into effect in October 1991 and heralded a significant turning point for land use planning. It not only ushered in the concept of 'sustainable management', but redefined how natural and physical resources such as land (inclusive of buildings), air and water are to be managed. Inherent within this redefinition is a strengthened legal imperative that requires those exercising policy or decision making powers under the Act to actively afford protection to places of identifiable heritage value.

\section{(i) Purpose and Principles}

The purpose of the RMA is 'to promote the sustainable management of natural and physical resources' [s.5(1)]. Included within the ambit of these resources are 'land, water, air, soil... and all structures'. ${ }^{13}$

To achieve this purpose the Act requires any person ${ }^{14}$ with responsibilities for managing the use, development, and protection of natural and physical resources to 'recognise and provide for' the following matters of national importance: ${ }^{15}$

- the protection of outstanding natural features and landscapes from inappropriate subdivision and development [s.6(b)];

- the relationship of Maori to their culture and traditions with their ancestral lands, water, sites, waahi tapu, and other taonga $[\mathrm{s} .6(\mathrm{e})] \mathrm{i}^{16}$

- the protection of historic heritage from inappropriate subdivision, use and development [s.6(f)]; ${ }^{17}$ and

- the protection of recognised customary activities [s.6(g)]. ${ }^{18}$

Within the context of the RMA historic heritage is defined as 'those natural and physical resources that contribute to an understanding and appreciation of New Zealand's history and cultures, deriving from any of the following qualities: archaeological, architectural, cultural, historic, scientific, and technological; and includes: historic sites, structures, places and areas; archaeological sites; sites of significance to Maori, including wahi tapu; and surroundings associated with the natural and physical resources' [s.2]. ${ }^{19}$

In addition to these matters of national importance other matters that those exercising responsibilities must 'have particular regard' to include:

- kaitiakitanga [s.7(a)]; ${ }^{20}$ and

- the maintenance and enhancement of amenity values [s.7(c)]. ${ }^{21}$ 
Overarching these specific requirements is a further obligation to take into account the principles of the Treaty of Waitangi [s.8]. ${ }^{22}$

\section{(ii) Administration}

The primary agencies responsible for giving effect to the purpose and principles of the RMA are regional councils and territorial local authorities. ${ }^{23}$ The specific accountabilities allied with each of these tiers of local government are outlined in ss.30 and 31. Of particular relevance to historic heritage protection and management is the requirement that:

- regional councils establish, implement and review 'objectives, policies and methods to achieve integrated management of the natural and physical resources of the region' [s.30(1)(a)], and prepare 'objectives and policies in relation to any actual or potential effects of the use, development or protection of land which are of regional significance' [s.30(1)(b)]; and

- territorial local authorities establish, implement and review 'objectives, policies and methods to achieve integrated management of the effects of the use, development or protection of land and associated natural and physical resources of the district' [s.31(1)(a)].

The vehicle by which these functional requirements are implemented is through regional policy statements, regional plans and district plans. Regional policy statements and plans are prepared and administered by regional councils, while district plans are prepared and administered by territorial local authorities.

\section{(iii) Protective Measures}

The protection of historic heritage under the RMA is generally facilitated through the policy and regulatory framework contained in policy statements and plans or through the use of heritage orders. ${ }^{24}$

At the regional level, policy statements and plans provide a means to identify and protect historic heritage considered to be nationally or regionally significant, ${ }^{25}$ or which is in or on any foreshore or seabed in the coastal marine area. ${ }^{26}$ They also act as a mechanism to ensure that such places are appropriately protected in district plans prepared by constituent territorial local authorities. ${ }^{27}$

At the territorial level, the 'effects of the use, development and protection' of historic heritage are generally managed through the identification of important places or areas in a schedule or register annexed to a district plan, and the application of specific rules and associated resource consent processes to these places. ${ }^{28}$ The range of activities generally covered by such rules include, for example, the alteration/modification or demolition/destruction of listed buildings or sites. ${ }^{29}$ 
Where such rules exist, any application for consent to undertake work which is not directly permitted by a district plan must include, amongst other matters, an assessment of environmental effects [s.88(2)(b)]. In particular, this requires an applicant to:

- provide a description of possible alternative locations or methods for any proposal that is likely to affect a recognised customary activity [cl.1A Fourth Schedule]; and

- consider 'any effect on natural and physical resources having aesthetic, recreational, scientific, historical, spiritual or cultural, or other special value for present or future generations' [cl.2(d) Fourth Schedule].

In the course of preparing regional or district plans local authorities ${ }^{30}$ are obliged to 'have regard to any relevant entry in the Historic Places Register' [ss.66(2)(c)(iia) \& $74(2)$ (b)(iia)]. This, in turn, provides a means of ensuring that places identified in this 'statutory' register are not overlooked. During this process local authorities are also required to ensure that their plans:

- 'have regard to' any management plans and strategies prepared under other legislation [ss.66(2)(c)(i) \& 74(2)(b)(i); $]^{31}$

- 'recognise and provide for' any management plan lodged for an adjoining foreshore and seabed reserve [ss.66(2A)(b) \& 74(2A)(b); $]^{32}$ and

- 'take into account' any recognised planning document lodged by an iwi authority [ss.66(2A)(a) \& 74(2A)(a)].

In contrast to the more 'generic' requirements relating to policy statements and plans, those that are associated with a notice of requirement for a heritage order are more specifically focused. ${ }^{33}$ In essence, the purpose of a heritage order is to protect:

- places of 'special interest, ${ }^{34}$ character, intrinsic or amenity or visual appeal, or of special significance to tangata whenua for spiritual, cultural or historic reasons' [s.189(1)(a)]; and

- any area of land around the place necessary to ensure its 'protection and reasonable enjoyment' [s.189(1)(b)].

Heritage orders can only be imposed by a recognised heritage protection authority ${ }^{35}$ and have interim effect from the date that a notice is served on a territorial local authority. ${ }^{36}$ Once confirmed, they are required to be included in the relevant district plan and require the approval of the heritage protection authority prior to the 
commencement of any work, subdivision or change of use that could nullify the effect of the order [s.193].

Although heritage orders are a 'useful protection mechanism for important heritage places where there is an imminent threat of damage or destruction or where plan provisions are not sufficient', ${ }^{37}$ they have only been sparingly applied to date. This, in turn, may be 'attributable to the clear rights to compensation spelt out in Section 198 of the Act'. ${ }^{38}$

Regardless of the apparent opportunities to regulate for protection of historic heritage through such mechanisms as provisions in plans and heritage orders, it is also important to recognise that such powers are not unfettered. In particular, s.32 imposes a duty on those wishing to exercise regulatory powers to undertake an evaluation to examine:

- the extent to which each identified objective is the most appropriate way to achieve the purpose of the Act [s.32(3)(a)]; and

- whether, in terms of efficiency and effectiveness, the policies, rules or other methods proposed are the most appropriate means to achieve these objectives [s.32(3)(b)].

In carrying out this task the following factors also need to be considered:

- the benefits and costs of the policies, rules or other methods proposed [s.32(4)(a)]; and

- the risk of acting or not acting if there is uncertain or insufficient information about the subject matter to which these apply [s.32(4)(b)].

The net result of applying the rigour inherent in this requirement is that reliance on regulatory, as opposed to non-regulatory, ${ }^{39}$ means to protect historic heritage needs to be carefully assessed and judiciously exercised.

\section{(iv) Offences and Enforcement}

To ensure that individuals comply with the statutory requirements set out in the Act, specific enforcement provisions have been incorporated to address identifiable contraventions. ${ }^{40}$ These provisions, in turn, are administered by the Environment Court and extend to include, for instance:

- the cessation or prohibition of anything that contravenes or is likely to contravene the Act, a rule in a plan or proposed plan, a requirement for a designation or heritage order or a resource consent [s.314(1)(a)(i)]; and 
- the issuing of specific directions to enforce compliance with the Act, a rule in a plan or proposed plan, a requirement for a designation or heritage order or a resource consent [s.314(1)(b)(ii)].

In the event of non-compliance, further powers available to the Court include, for example, the ability to convict any person to a term of up to two years imprisonment or to impose a fine of up to $\$ 200,000$ [s.339 (1)]. ${ }^{41}$

\section{HISTORIC PLACES ACT $1993^{42}$}

The HPA 1993 represents the most recent iteration of legislation specifically directed towards the identification and protection of historic and cultural heritage.$^{43}$ It primarily focuses on the establishment of a system of registration for historic places, historic areas, wahi tapu and wahi tapu areas and the control of any works that could adversely affect archaeological, Maori or other relevant values associated with an archaeological site. The Act also establishes the New Zealand Historic Places Trust (NZHPT) and the Maori Heritage Council and defines their respective roles and responsibilities.

\section{(i) Purpose and Principles}

The primary purpose of the HPA is 'to promote the identification, protection, preservation, and conservation of the historical and cultural heritage of New Zealand' [s.4(1)].

To achieve this, s.4(2) of the Act requires those exercising functions and powers under it to recognise a series of principles which include, for example:

- that 'historic places ${ }^{44}$ have lasting value in their own right and provide evidence of the origins of New Zealand's distinct society' [s.4(2)(a)]; and

- that the 'identification, protection, preservation, and conservation of New Zealand's historical and cultural heritage should take account of all relevant cultural values, knowledge and disciplines' [s.4(2)(b)(i)].

To ensure that appropriate account is given to the Treaty of Waitangi the HPA contains a requirement that it 'must continue to be interpreted and administered to give effect to the principles of the Treaty of Waitangi, unless the context otherwise requires' [s.115(2)]. The Act also stipulates that recognition be given to the 'relationship of Maori and their culture and traditions with their ancestral lands, water, sites, wahi tapu and other taonga' [s.4(2)(c)].

\section{(ii) Administration}

Although overall responsibility for administering the HPA rests with the Ministry for 
Culture and Heritage $(\mathrm{MCH}),{ }^{45}$ the agency that is charged with 'full and proper attainment of the objectives of the Act' [Long Title] is the NZHPT.

A particularly important means by which the Trust endeavours to accomplish this role is through the maintenance and ongoing development of its register of

historic places, historic areas, wahi tapu and wahi tapu areas [s.22]. ${ }^{46}$ The register, in turn, performs an essential function in that it:

- informs members of the public about places and areas of historic heritage value;

- notifies the owners of these places and areas where this is required by the Act;

and

- assists in the protection of these places and areas under the RMA.

Although the Trust assumes primary accountability for the register, proposals to include additional places or areas can be submitted by any person [s.24(1)]. The ultimate decision, however, as to whether a place or area should be entered on the register rests with the Trust or the Maori Heritage Council. In coming to a decision on this matter either body is guided by the extent to which there is clear evidence that the place or area possesses 'aesthetic, archaeological, architectural, cultural, historical, scientific, social, spiritual, technological, or traditional significance or value' [s.23(1)].

If a place or area is identified as embodying one or more of these attributes ${ }^{47}$ s.23(2) outlines the procedure whereby either 'Category l' or 'Category II' status is assigned. ${ }^{48}$ In determining the level of importance to be applied to a particular place or area the Trust is guided by a further series of criteria that includes, for example, such matters as representativeness, scientific or educational potential, ethnic or community associations, rarity, and landscape integrity [s.23(2)(a)-(m)].

In registering historic places and wahi tapu the Trust is required to publicly notify the place to which the registration applies and to specifically notify the owner, any person having a registered interest in the place, and the relevant local authority. ${ }^{49}$ Interestingly, there is no right of objection to the outcome of this process although this is compensated for by the fact that registration does not, in itself, confer protection over any place or area included in the register. ${ }^{50}$

With respect to the registration of historic and wahi tapu areas, the Trust can make recommendations to local authorities regarding measures they should take to facilitate the conservation and protection of areas under their jurisdiction. In the event that this recommendatory function is exercised, the local authority concerned is required to 'have particular regard to the Trust's recommendations' [ss.31(5) \& $32(5)$. $^{51}$ 


\section{(iii) Protective Measures}

Protection of historic places and areas under the HPA is largely facilitated by way of heritage orders, heritage covenants, administration of archaeological authorities and interim registration.

Under the HPA the Trust and the Minister of Arts, Culture and Heritage are identified as having specific authority to seek a heritage order under the RMA for the purposes of protection [s.5]. ${ }^{52}$ Places over which a heritage order can be sought include:

- the 'whole or part of any historic place, historic area, wahi tapu, or wahi tapu area' [s.5(a)]; and

- any area of land surrounding these places or areas in order to ensure their 'protection and reasonable enjoyment' [s.5(b)].

By contrast, heritage covenants comprise a voluntary form of protection that consists of a contractual agreement being entered into between the Trust and an owner, lessee or licensee of a place or area [s.6]. Covenants generally include terms and conditions specific to the property and have effect in perpetuity. As they are registered on the title they 'run with the land' and consequently bind all subsequent property owners.

In terms of archaeological sites, ${ }^{53}$ the Act imposes 'blanket' protection over all such sites irrespective of whether they are currently registered or recorded [s.10]. The resultant effect of this requirement is that the consent of the Trust must be obtained prior to any activity being undertaken which would destroy, damage or modify the whole or any part of:

- any archaeological site; or

- all archaeological sites within a specified area; or

- any class of archaeological site within a specified area of land [ss.11 \& 12].

Any declaration, decision, condition or review of any decision made or imposed by the Trust in relation to any such consent may, however, be appealed to the Environment Court [s.20]. ${ }^{54}$

Protection is also provided to historic places and wahi tapu under consideration for inclusion in the register [s.27]. Any proposal which satisfies the Trust's test of 'sufficient evidential proof' enjoys interim protection from the time that it is publicly notified until either final registration is confirmed or a period of six months has elapsed [s.26(3)]. During this period the consent of the Trust is required for any work or activity that has the potential to negate the effect of interim protection (eg. The 
demolition or destruction of a place or site). ${ }^{55}$

\section{(iv) Offences and Enforcement}

In addition to these protective mechanisms, the HPA also affords the Court the power to impose a fine on any person who intentionally destroys, damages or modifies any historic place/area or wahi tapu/area that is either under the control of the Trust, is an archaeological site, or which is subject to interim protection or a heritage covenant. In the case of the destruction of historic places, historic areas and archaeological sites the maximum fine that can be imposed is $\$ 100,000$, while intentional damage or modification of such places attracts a maximum fine of $\$ 40,000$ [ss.97-103]. ${ }^{56}$

Where an owner or occupier is convicted of illegally demolishing or destroying any land or place that is subject to interim protection or a heritage order, the Act also authorises the Court to make an order restricting redevelopment or the establishment of certain permitted activities on that land for a period of up to five years [s.105(1)].

\section{CONSERVATION ACt 1987}

Essentially the CA establishes the Department of Conservation (DoC) and mandates it to assume a central role in the protection and management of historic heritage located on or off any land that the department owns or administers. ${ }^{57}$

\section{(i) Purpose and Principles}

Unlike the RMA and HPA there is no explicit purpose or associated principles identified in the CA. Regardless of this, the long title states that it is an Act 'to promote the conservation of New Zealand's natural and historic resources', ${ }^{58}$ and that in interpreting and administering its statutory duties and obligations DoC is required to give effect to the principles of the Treaty of Waitangi [s.4].

\section{(ii) Administration}

DoC is the primary administrative agent of the CA. Amongst the range of functions that the department assumes under the Act are:

- managing land and historic places and areas that it owns or administers [s.6(a)];

- acting as an advocate for the preservation and protection of historic places and areas [s.6(b)];

- $\quad$ promoting the benefits associated with the preservation and protection of historic places and areas in New Zealand to present and future generations [s.6(c)]; and

- providing and publishing information relating to conservation [s.6(d)].

The basic means by which DoC gives effect to its functional obligations is through the 
preparation of conservation management strategies [s.17D] and associated management plans [s.17E]. Together these mechanisms provide an 'integrated' policy framework for the management of historic resources under the control of the department.

Conservation management strategies are essentially conservancy based ${ }^{59}$ and identify general policies and objectives that cover the wide spectrum of work that each conservancy undertakes. As these strategies are broadly focused they do not include detailed information that relates, for example, to the management of specific historic areas located within a conservancy. This level of detail is generally addressed in any subsequent conservation management plan developed for these areas. Once prepared, DoC has a duty to 'administer and manage all conservation areas and natural and historic resources' in accordance with these strategies and plans [s.17A].

\section{(iii) Protective Measures}

To a large extent historic places located on land owned or administered by DoC are less vulnerable to the pressures experienced elsewhere due to their Crown-owned status and the management obligations incumbent on the department.

Regardless of this, the Act provides for more tailored protection of specific sites or areas through, for example, the conferral of additional protective requirements over such areas by the Minister of Conservation [ss.18 \& 19], ${ }^{60}$ and by way of covenants [s.27], Nga Whenua Rahui kawenata [s.27A] ${ }^{61}$ and management agreements [s.29]. ${ }^{62}$

\section{(iv) Offences and Enforcement}

Like the RMA and HPA, the CA includes provision for the Court to impose a fine to remedy deliberate damage to any historic features located within a conservation area. The maximum that can be imposed on any individual is $\$ 10,000$, while corporations are liable to a maximum fine of up to $\$ 80,000$ [s.44]. ${ }^{63}$

However, in the event that a fine is considered to be an inadequate penalty or deterrent, the Act also empowers the Court to impose a term of imprisonment of up to one year [s.44]. Additionally, the CA enables the Crown to forfeit any property that has been used in the process of committing an offence [s.46].

\section{AdDITIONAL LEGISLATIVE SignPOSTS}

Despite the important role that the RMA, HPA and CA play in facilitating the protection and management of New Zealand's historic heritage, other legislation exists which also actively contributes to this endeavour. To provide some insight into the nature of these contributions, a small sample of those statutes which impact on historic heritage - the Reserves Act 1977 (RA), the Foreshore and Seabed Act 2004 
(F\&SA), the Antiquities Act 1975 (AA), the Building Act 2004 (BA) and the Ngai Tahu Claims Settlement Act 1998 (NTCSA) - will now be briefly examined.

\section{Reserves Act 1977}

The general purpose of the RA includes, amongst other matters, provision for the preservation and management of areas possessing historic, cultural, or archaeological features or values for the 'benefit and enjoyment' of the New Zealand public [s.3(1)]. To achieve this purpose the RA enables such areas to be classified as historic and local purpose reserves. Under the Act historic purposes reserves are required to be administered and maintained in such a way that:

- the 'structures, objects and sites illustrate with integrity the history of New Zealand' [s.18(2)(a)]; and

- where archaeological features are present they be 'managed and protected to the extent compatible with the principal or primary purpose of the reserve' $[\mathrm{s} .18(2)(\mathrm{c})]^{64}$

Similarly, on local purpose reserves any historic or archaeological features present are to be 'managed and protected to the extent compatible with the principal or primary purpose of the reserve' [s.23(2)(a)].

Accountability for administering the Act rests primarily with $\mathrm{DoC}^{65}$ although the Minister of Conservation is empowered to vest reserves in 'administering bodies' such as local authorities [s.26(1)] ${ }^{66}$ and to appoint such bodies to control and manage reserves that are vested in the Crown [ss.28-30].

In order to 'provide for and ensure the use, enjoyment, maintenance, protection, and preservation' of reserves, the RA requires that every administering body prepare a management plan for every reserve under its control [s.41(1)]. The Act also identifies mechanisms to secure the protection of land that is considered to be of importance to the public and/or Maori. These include conservation covenants to protect private land which possesses identifiable historic, cultural or archaeological qualities [s.76] and Nga Whenua Rahui kawenata [s.77A]. ${ }^{67}$

To encourage compliance the RA contains penalty provisions that are intended to deter interference with, or damage to, any 'recreational, scenic, historic, scientific or natural features' within a reserve [s.94(1)(m)]. Where an individual commits any such offence on a nationally important reserve the Act permits the imposition of a term of imprisonment not exceeding three months or a maximum fine of $\$ 2,500$. On all other reserves the potential term of imprisonment is reduced to one month or a fine not exceeding $\$ 500$ can be imposed [s.103(a)]. ${ }^{68}$ 
Forshore And Seabed Act $2004^{69}$

The principal objective of the F\&SA is to 'preserve the public foreshore and seabed in perpetuity as the common heritage of all New Zealanders' [s.3]. To achieve this the Act provides for the 'recognition and protection of ongoing customary rights to undertake or engage in activities, uses or practices in areas of the public foreshore and seabed' [s.4(b)]. Customary rights are rights that have been continuously exercised over an area and which predate the assumption of Crown ownership. ${ }^{70}$ The Act codifies common law and provides for the recognition of these rights in the form of customary rights orders. ${ }^{71}$

Antiquities Act $1975^{72}$

The intent of the AA is to "provide for the better protection of antiquities, ${ }^{73}$ to establish and record the ownership of Maori artifacts ${ }^{74}$ and to control the sale of artifacts within New Zealand' [Long Title]. The Act is administered by the Ministry for Culture and Heritage $(\mathrm{MfCH})$ and concentrates on three key areas: ${ }^{75}$

- determining the ownership and custody of artifacts;

- regulating the trade of artifacts; and

- placing limitations on the export of antiquities.

With respect to the matter of export, the removal of any antiquity from New Zealand without a written certificate of permission from the Chief Executive of the $\mathrm{MfCH}$ is illegal and subject to the imposition of a fine not exceeding $\$ 100,000$ [s.5]. ${ }^{76}$

In terms of ownership and custody, the Act clearly specifies that any artifact found in New Zealand is 'prima facie the property of the Crown', ${ }^{77}$ including any artifact found during the course of an archaeological investigation under the HPA [s.11]. ${ }^{78}$ However, in circumstances where an artifact is 'recovered from the grave of any person or persons whose identity is known', the Maori Land Court assumes jurisdictional authority [s.11(1)].

The Maori Land Court also has jurisdiction to decide traditional ownership of an artifact. ${ }^{79}$ Particular matters that it is empowered to make a determination on include custodial entitlement, the status of a recovered article (that is, whether or not it is an artifact) and the vesting of an artifact in any person for the purposes of preservation and safekeeping [s.12]. ${ }^{80}$ Restrictions are also imposed on the sale or disposal of artifacts with those authorised to engage in their purchase being limited to registered collectors, public museums or the offices of a licensed auctioneer or secondhand dealer [s.13]. ${ }^{81}$

Building Act 2004

Amongst the range of matters that the BA endeavours to provide for is the 
establishment of appropriate building standards to ensure that 'people who use buildings can do so safely and without endangering their health' [s.3(a)], and that buildings are 'designed, constructed and able to be used in ways that promote sustainable development' [s.3(d)]. To achieve this, those charged with the exercise of any function, duty or power under the Act are required to 'take into account' the need to 'facilitate the preservation of buildings of significant cultural, historical or heritage value' $[s .4(2)(I)]$. One of the primary ways in which this requirement is given effect is through territorial local authorities issuing project information memoranda (PIMs) to building owners contemplating any work that requires a building permit [s.32]. Information to be provided includes the heritage status (if any) of the building to which the permit applies [s.35(1)(a)(i)].

The inclusion of this information in a PIM not only provides a means of drawing to the attention of property owners the existence and importance of heritage buildings located on their property, but also provides a useful catalyst to encourage specialist advice to be sought prior to lodgement of a building consent. ${ }^{82}$ Where an application for a PIM relates to any building work that will affect a 'registered historic place, historic area, wahi tapu, or wahi tapu area' the territorial local authority is also required to advise the NZHPT [ss.35(1)(f) \& 39]. ${ }^{83}$

To ensure that buildings remain 'safe', the BA contains specific requirements relating to those considered to be 'earthquake prone'. ${ }^{84}$ In particular, the Act requires territorial authorities to adopt a policy on earthquake prone buildings inclusive of a statement as to how the policy will apply to heritage buildings [s.131]. The intent of this statement is to outline how the territorial authority intends to manage heritage buildings in light of the particular set of considerations and constraints affecting these buildings including: 85

- meeting the requirements of the HPA;

- dealing with owners and the NZHPT;

- considering the different needs of private and public owners of heritage buildings; and

- $\quad$ providing incentives for owners to upgrade their buildings.

Ngai Tahu Claims Settlement Act $1998^{86}$

The general statutory intent of the NTCSA is to 'record the apology given by the Crown to Ngai Tahu in the deed of settlement executed on 21 November 1997' and to 'give effect to certain provisions of that deed of settlement' [Long Title]. Included amongst the provisions addressed within the NTCSA is an acknowledgement by the Crown of the statements made by Te Runanga o Ngai Tahu regarding the cultural, spiritual, historic and traditional association of Ngai Tahu with a number of identified statutory areas [s.206]. ${ }^{87}$ 
To ensure that effect is given to this statutory acknowledgement the NTCSA requires that relevant local authorities, the Environment Court and the NZHPT 'have regard to' Ngai Tahu interests in relation to the management of the statutory areas identified. Consequently, in the course of deliberating on such matters as:

- parties likely to be affected by a resource consent application;

- parties from whom written approval must be sought for non-notified consent applications; and

- legal standing before the court.

Consideration must be given by these agencies to whether the application relates to a statutory area over which Te Runanga o Ngai Tahu has a vested interest [ss.208$210]^{88}$

\section{CONCLUSION}

What is evident from this overview is that there currently exists within the New Zealand legislative landscape a myriad of statutes that impinge on historic heritage. The seemingly disassociated nature of this 'framework' of legislative provisions stimulated reviews in the 1990's that called for the adoption of a more integrated approach to the protection and management of historic heritage, particularly with respect to the RMA, HPA and CA. ${ }^{89}$

As a result of these reviews amendments have been included in the RMA, and changes proposed to the HPA, that attempt to promote better integration between these statutes and strengthen the imperative to protect historic heritage through such instruments as policy statements and plans. The effectiveness of these changes, however, will only become apparent as these planning instruments are reconsidered in light of the enhanced requirements.

\section{ENDNOTES}

\footnotetext{
${ }^{1}$ For the purpose of this article the term 'historic heritage' assumes the same meaning as that defined in section 2 of the RMA 1991.

${ }^{2}$ Peter James, A Guide to the Legal Protection of the National Estate in Australia as at 31 December 1994, Australian Government Publishing Service, Canberra, 1995, pp3-4.

${ }^{3}$ Michael Pearson and Sharon Sullivan, Looking After Heritage Places: The Basics of Heritage Planning for Managers, Landowners and Administrators, Melbourne University Press, Melbourne, 1995, p35.

${ }^{4}$ David Butts, 'Institutional Arrangements for Cultural Heritage Management in New Zealand: Legislation, Management and Protection', in C. Michael Hall and Simon McArthur (eds), Heritage Management in New Zealand and Australia: Visitor Management, Interpretation and Marketing, Oxford University Press, Auckland, 1993, pp171-172.

${ }^{5}$ Brett Jones, 'Saving Our Cultural Heritage - Historic Buildings: A Critical Interpretation of New Zealand Legislation, its Usage, and Policy Recommendations for the Future', unpublished MA thesis, University of Auckland, 1994, p39.

${ }^{6}$ Peter James, p6.

${ }^{7}$ Pearson and Sullivan, p37.
} 

${ }^{8}$ As well as the protective provisions currently embedded in New Zealand law the government is also a
signatory to the UNESCO Convention on the Protection of the World Cultural and Natural Heritage.

9 The investigation into Historic and Cultural Heritage Management in New Zealand that was undertaken by the Office of the Parliamentary Commissioner for the Environment in 1996 identified a total of 20 statutes that either provided for, or impacted upon, historic heritage protection.

${ }^{10}$ Additional statutes identified in Parliamentary Commissioner for the Environment, Historic and Cultural Heritage Management in New Zealand, Parliamentary Commissioner for the Environment, Wellington, 1996, ppA7-A14 include: Conservation Act 1987; Environment Act 1986; Reserves Act 1977; National Parks Act 1980; The Building Act 1991 (superceded in 2004); Earthquake Commission Act 1993; Queen Elizabeth the Second National Trust Act 1977; New Zealand Walkways Act 1990; Gaming and Lotteries Act 1977; Museum of New Zealand Te Papa Tongarewa Act 1992; Antiquities Act 1975; Treaty of Waitangi Act 1975; Local Government Official Information and Meetings Act 1987; Te Ture Whenua Maori/Maori Land Act 1993; State-Owned Enterprises Act 1986; Valuation of Land Act 1951; and Waitangi National Trust Board Act 1932.

${ }^{11}$ This section incorporates relevant changes introduced by the RM Amendment Act 2003 (RMAA 2003), the RM (Foreshore and Seabed) Amendment Act 2004 (RM(F\&S)AA 2004) and the RM Amendment Act 2005 (RMAA 2005).

${ }_{12}$ Parliamentary Commissioner for the Environment, pA7.

${ }^{13}$ The term 'structures' is further defined under s.2 as 'any building, equipment, device or other facility made by people which is fixed to land'.

${ }^{14}$ The definition of 'person' in s.2 of the RMA is quite wide ranging in scope and includes 'the Crown, a corporation sole, and also a body of persons whether corporate or unincorporate'. Obvious examples of important entities in relation to historic heritage include the Department of Conservation and city, district and regional councils.

${ }^{15}$ Despite the strong protective bias embedded within these sections of the Act, Environment Court Judge Shonagh Kenderdine cautions that 'under the attributes of sustainable management the protection of historic heritage is not an absolute'. Sourced from Shonagh Kenderdine, Heritage Landscapes: Developing legislative frameworks which allow for protection and change, Proceedings of the Looking Forward to Heritage Landscapes Conference, Dunedin, 2005, p39.

${ }^{16}$ Harry Allen suggests, however, that Maori are 'poorly served by heritage conservation' and that the procedures and institutions established by such statutes as the RMA do not take wide enough account of Maori needs. He points out that a 'multiplicity of places of significance to Maori are forced into categories such as wahi tapu or historic place' which, in turn, end up being 'managed through a legalistic process that has more to do with property rights than with negotiated outcomes'.

Sourced from Harry Allen, Protecting Historic Places in New Zealand, Department of Anthropology, University of Auckland, 1998, p10.

${ }_{17}$ Geraldine Baumann and Claire Heather observe that although historic heritage has been elevated to a s. 6 matter 'it is yet to be seen the difference this change in the RMA will bring to the preservation of historic heritage. Current district plans will in due course have to be reconsidered in light of the new emphasis required'. Sourced from Geraldine Baumann and Claire Heather, 'Protecting Historic Heritage' in Rob Harris (ed), Handbook of Environmental Law, Royal Forest and Bird Protection Society, Wellington, 2004, p505.

${ }^{18}$ Recognised customary activities were introduced into the Act through the RM(F\&S)AA 2004. They are defined in s.2 as 'any activity, use, or practice carried on, exercised, or followed under a customary rights order'. A customary rights order is an order imposed by either the Maori Land Court or the High Court over an area of the public foreshore and seabed to recognize a particular activity, use or practice that has been carried out on an area of the public foreshore and seabed since 1840 [refer ss.2, 50 \& 74 F\&SA 2004].

${ }_{19}$ The RMA is the only statute that specifically refers to and defines historic heritage. By contrast, the HPA and CA refer to places that contribute to New Zealand's historic and cultural heritage as 'historic places' and 'heritage resources' respectively.

${ }^{20}$ Generally refers to the exercise of guardianship.

${ }^{21}$ These are defined in s.2 of the RMA as 'the natural or physical qualities or characteristics of an area that contribute to people's appreciation of its pleasantness, aesthetic coherence, and cultural and recreational attributes'.

${ }^{22}$ The Court of Appeal in New Zealand Maori Council v Attorney General [1987] 1 NZLR 641 established that there are two core principles associated with the Treaty - 'partnership' and 'active protection'. The former includes the obligation on the part of both the Crown and Maori to act reasonably, honourably and in good faith, while the latter involves the Crown actively protecting the interests of Maori to use their lands and waters to the fullest extent practicable.

${ }^{23}$ The term 'territorial local authorities' includes both city and district councils. Aside from the RMA territorial local authorities also play an important role in interpreting and implementing a number of other statutes referred to in this paper including, for example, the HPA, RA and BA.

${ }^{24}$ Recognised customary activities are an exception. Regardless of any restrictions in a plan that might apply to these activities, they can commence without a resource consent where they are (1) carried out by a member of 
a tribal group that is the holder of a customary rights order or are their authorised nominee and (2) in accordance with any controls imposed by the Minister of Conservation [s.17A].

${ }^{25}$ Most of the regional policy statements that have been prepared to date include a section relating to historic heritage but as the report prepared by the Parliamentary Commissioner for the Environment, 1996, p34, observes: they generally 'do not develop issues significantly beyond what is currently undertaken by territorial authorities in the region'. It is important to note here, however, that a major exception is the Auckland Regional Council which has assumed a key management role in the Auckland region in the areas of inventory, evaluation, resource consent processes and policy development.

${ }^{26}$ Under s.12(g) any activity that will 'destroy, damage or disturb any foreshore or seabed (other than for the purpose of lawfully harvesting any plant or animal) in a manner that has or is likely to have an adverse effect on historic heritage' is restricted unless it is permitted by a rule in a regional coastal plan or resource consent approval has been obtained.

${ }^{27}$ District plans are required to 'give effect to any regional policy statement' [s.75(3)(c)] and to be consistent with any associated plan prepared by a regional council to assist it with the exercise of its statutory functions $[\mathrm{s} .75(4)(\mathrm{b})]$.

${ }^{28}$ Although this is the principal method that has been historically relied upon by territorial local authorities to protect historic heritage, it is important to recognise that neither the methods used nor the level of protection provided within a district plan is stipulated in the RMA. The ultimate determination of these matters rests with councils and their respective communities through the consultation and decision making process allied with plan development.

${ }^{29}$ However, under s.85A of the RMA regional and district plans are not allowed to describe an activity as permitted if it is likely to have a significant adverse effect on a recognised customary activity. Section 107A(1) further requires that any consent application received by a local authority to do anything that will, or is likely to, result in a significant adverse impact on such activities be declined unless the written approval of the holder of the customary rights order has been obtained.

${ }^{30}$ The term 'local authority' encompasses both territorial local authorities and regional councils.

${ }^{31}$ Like, for instance, the Conservation Act 1987, Reserves Act 1977 and Local Government Act 2002.

${ }^{32}$ The primary purpose of a foreshore and seabed reserve is to recognise the exercise of guardianship by the applicant group and to enable the area concerned to be held for the common use and enjoyment of the general public.

${ }^{33}$ Refer ss.187-198 of the RMA.

${ }^{34}$ This includes places that have special cultural, architectural, historical, scientific, ecological or other interest.

${ }^{35}$ Under S.187 of the RMA recognised heritage protection authorities include Ministers of the Crown, local authorities, the NZHPT and any relevant body corporate approved by the Minister for the Environment.

${ }^{36}$ The date on which the interim effect of a notice of requirement for a heritage order ceases to apply is either the day on which the notice is withdrawn by the heritage protection authority/cancelled by the Environment

Court or the order is included in a district plan.

${ }^{37}$ New Zealand Historic Places Trust, Heritage Management Guidelines for Resource Management

Practitioners, New Zealand Historic Places Trust, Wellington, 2004, p20.

${ }^{38}$ Brent Nahkies, The Economics of Heritage Buildings: A Contribution to the Historic Heritage Management

Review, New Zealand Historic Places Trust, Wellington, 1998, p18.

${ }^{39}$ Non-regulatory means include, for example, rating relief; access to grants aid and low interest loans; provision of information and advice; and reduction or waiving of financial contributions or fees.

${ }^{40}$ Refer ss.314-321 of the RMA.

${ }^{41}$ Regardless of the perceived severity of such penalties their effectiveness as a disincentive to non-compliance is questionable. In terms of the redevelopment of a prime central city site, for example, the imposition of a $\$ 200,000$ fine for the illegal demolition of a building of historic heritage value is likely to have a minimal impact on return and may end up being significantly less than the holding costs associated with proceeding by way of a consent process.

${ }^{42}$ At the time of writing Parliament is considering a Bill to amend the HPA. To aid understanding of the impact of the proposed changes included in the Historic Places Amendment Bill 2004 (HPAB), reference to specific amendments that are relevant to the content of this section are incorporated into the following endnotes.

${ }^{43}$ Preceding Acts of Parliament include the Historic Places Act 1954, the Historic Places Amendment Acts of 1963 and 1975 and the Historic Places Act 1980.

${ }^{44}$ Under s. 2 of the HPA an historic place is defined as: (a) any land (including an archaeological site); or any building or structure (including any part of a building or structure); or any combination of land a building or structure that forms part of the historical and cultural heritage of New Zealand and lies within the territorial limits of New Zealand; and (b) includes anything that is in or fixed to such land. In order to clarify that the definition covers more than one associated building or structure the HPAB proposes to include a further category as follows: 'any combination of land, buildings or structures and associated buildings or structures (including any part of those buildings or structures, or associated buildings or structures) [Pt.1, cl.3(1)].

${ }^{45}$ The $\mathrm{MCH}$ is the principal heritage policy advisor to the Crown. It also supervises and monitors, on behalf of the Crown, the purchase agreement for heritage management services provided by the Trust. 
${ }^{46}$ The NZHPT Cultural Heritage Planning Manual (1994) notes that the category of historic place not only applies to buildings but that it also includes trees, cemeteries, industrial structures and gardens. Additionally, given the broad definition of 'historic place' and 'wahi tapu' contained in s.2 of the HPA it is possible for buildings located on a marae, for instance, to be considered under either category.

${ }^{47}$ It is useful to note here that a place or area does not have to satisfy all of the criteria contained in s.22(1) and may be considered for entry in the register where only one of these criteria has been met.

${ }^{48}$ Under s.22(3)(a) Category I places are defined as those which are of 'special or outstanding historical or cultural heritage significance or value' while those in Category II are defined as places which are of 'historical or cultural heritage significance or value'.

${ }^{49}$ In response to a review of registration undertaken by Professor Peter Skelton in 2004 the HPAB proposes a number of amendments to ensure more consistent notification and submission processes for proposals [ie. Pt.1, cls.9-16].

${ }^{50}$ The principal regulatory means by which protection is achieved is through either district plans or heritage orders.

${ }^{51}$ The HPAB presently before Parliament takes this one step further by proposing that the imperative 'shall have particular regard' be replaced with 'must have particular regard' [Pt.1, cl.13, new s.32D(3)].

${ }^{52}$ The process by which a heritage order can be imposed on a historic place or area is set out in ss.187-198 of the RMA.

${ }^{53}$ These are defined under s.2 of the HPA as inclusive of any place that was either 'associated with human activity that occurred before 1900' or is the 'site of the wreck of any vessel where that wreck occurred before 1900 ' and 'which is or may be able through investigation by archaeological methods to provide evidence relating to the history of New Zealand'.

${ }^{54}$ To help clarify when an archaeological consent commences the HPAB proposes that any authority granted not take effect until either the relevant rights of appeal have expired or all appeals have been resolved [Pt 1 , cl.5, new s.20A(1)(a)].

${ }^{55}$ Refer to ss.194 \& 195 of the RMA.

${ }^{56}$ Refer endnote 30.

${ }^{57}$ In spatial terms the land area owned or administered by DoC comprises approximately $30 \%-35 \%$ of the total land area of New Zealand.

${ }^{58}$ Under s.2 of the CA the term 'conservation' is defined as 'the preservation and protection of natural and historic resources for the purpose of maintaining their intrinsic values, providing for their appreciation and recreational enjoyment by the public, and safeguarding the options of future generations', while the term 'historic resource' is defined as 'historic place within the meaning of the Historic Places Act 1993; and includes any interest in a historic resource'.

${ }^{59}$ New Zealand is divided into a total of 13 DoC conservancy areas.

${ }^{60}$ This would primarily be achieved through the declaration of an area as a 'conservation park'. Under s.19 of the CA every such park is required to be managed in such a way that 'its natural and historic resources are protected'.

${ }^{61} \mathrm{Nga}$ Whenua Rahui kawenata is a form of covenant entered into between the Crown and Maori that is applicable to land that is either in Maori ownership or Crown land that is held by Maori under a Crown lease. Its basic purpose is to provide for the management of any such land so as to preserve and protect either the historical value or the spiritual and cultural values that Maori associate with it.

${ }^{62}$ These include agreements, contracts or arrangements made between the Minister of Conservation and any other person in order to ensure that the conservation of a historic place located on his or her property is carried out.

${ }^{63}$ As these penalties generally apply to offences that have occurred on land which is part of the conservation estate they have the potential to be more effective than those that apply under the RMA and the HPA as the potential for pecuniary gain is much more limited.

${ }^{64}$ It is important to note here, however, that any work relating to an archaeological feature located on a historic reserve would also need to comply with the relevant provisions of the HPA.

${ }^{65}$ The Ministry for the Environment, however, is charged under s.31(c)(i) of the Environment Act 1986 with providing the Government, government agencies and other public authorities with advice on the application, operation and effectiveness of the RA

${ }^{66}$ Other bodies identified under s.2 of the RA include, for example, any Board, Trustees, society, association, or voluntary organisation.

${ }^{67}$ Refer endnote 45.

${ }^{68}$ Where an offence is committed by a corporation, the maxima for fines relating to national and other reserves is increased to $\$ 5000$ and $\$ 1000$ respectively. In addition to the imposition of a fine or a term of imprisonment for any transgression, s.94(6) of the RA provides that a person may also be liable to pay for the damage incurred.

${ }^{69}$ Also refer to the preceding section on the RMA as the amendments introduced by way of the Resource Management (Foreshore and Seabed) Amendment Bill 2004 provide the principal means by which customary rights are afforded protection. 
${ }^{70}$ Ministry of Justice, Main Elements of the Foreshore and Seabed Act: Customary Rights, 2004, www.justice.govt.nz/foreshore/main3.html

${ }_{71}^{71}$ Refer to endnote 16 above for the definition of customary rights orders.

${ }^{72}$ At the time of writing Parliament is considering a Bill to amend the AA. The intent of the Protected Objects Amendment Bill (POAB) 2005 is to provide, amongst other matters, a more precise definition of protected New Zealand objects subject to export regulation, and to prohibit the permanent export of protected objects that are of such significance that their export would diminish the nations cultural heritage. To aid understanding of the impact of the proposed changes included in the POAB, reference to specific amendments that are relevant to the content of this section are incorporated into the following endnotes.

${ }^{73}$ The term 'antiquities' generally applies to movable objects which include, for instance, artifacts, books, diaries, letters, photographs, film, pictures, animals, plants, minerals, meteorites, bones and feathers of extinct species, and aircraft or shipwrecks which are over 60 years of age [s.2]. The POAB proposes to delete reference to the term 'antiquity' in the principal Act and to replace it with 'protected New Zealand object'. This is defined as 'an object forming part of the moveable cultural heritage of New Zealand that (a) is of importance to New Zealand, or to part of New Zealand, for aesthetic, archaeological, architectural, artistic, cultural, historical, literary, scientific, social, spiritual, technological or traditional reasons and (b) falls within one or more of the categories of protected objects set out in Schedule 4. The categories of objects identified in Schedule 4 include, for example, art objects; Maori cultural objects; New Zealand archaeological objects; science, technology, industry, the economy and transport objects; and social history objects.

${ }^{74}$ The term 'artifact' as defined under s.2 of the AA is very wide in scope and includes 'any chattel, carving, object, or thing which relates to the history, art, culture, traditions, or economy of the Maori or other preEuropean inhabitants of New Zealand and which was or appears to have been manufactured or modified in New Zealand by any such inhabitant, or brought to New Zealand by an ancestor of any such inhabitant, or used by any such inhabitant, prior to 1902'. The POAB proposes to delete reference to the term 'artifact' in the principal Act and to replace it with 'taonga tuturu'. This is defined as an object that relates to Maori culture, history or society; was, or appears to have been manufactured or modified in New Zealand by Maori or; was brought into New Zealand by Maori or used by Maori; and is more than 50 years old.

${ }^{75}$ Ministry for Culture and Heritage, Administering the Antiquities Act, 2003, www.mch.govt.nz/antiquities

${ }^{76} \mathrm{~A}$ similar regime is proposed for 'protected New Zealand objects' under the POAB [s.5(1)]. However, in determining an export application the Chief Executive of the $\mathrm{MfCH}$ must consult two or more expert examiners [s.7B(2)]. If in the course of assessing an application they conclude that the object is 'of such significance to New Zealand or part of New Zealand that its export would substantially diminish New Zealand's cultural heritage', they are required to recommend to the chief executive that the application be declined [s.7D]. The Bill also strengthens the penalty provisions for export infringements. Any offence committed by an individual will be subject to either a fine not exceeding $\$ 1000$ or a term of imprisonment not exceeding 5 years, while any offence committed by a body corporate will be subject to a fine not exceeding $\$ 200,000$ [s.5(2)].

${ }^{77}$ This presumption is included in the AA to prevent newly discovered artifacts falling directly into private ownership.

${ }^{78}$ When an artifact is found s.11(3) of the AA requires that the Chief Executive of the $\mathrm{MfCH}$ to be notified within 28 days of the find or the completion of archaeological field work. Once notified the Chief Executive has discretion to determine whether the person who discovered the artifact should be given custody or whether custody should be granted to a public institution such as a museum. Any person who contravenes this requirement is subject to a fine not exceeding $\$ 500$. However, under the POAB this maxima is proposed to be increased to $\$ 10,000$ for an individual, and $\$ 20,000$ for a body corporate, for each taonga tuturu discovered.

${ }^{79}$ The application of the Maori Land Court's jurisdiction is currently governed by the provisions of s.30(1)(f) of the Maori Affairs Act 1953. The POAB proposes to instead link the exercise of the Court's power to s.30 (and any other relevant provision) of the Te Ture Whenua Maori Act 1993. This change has the potential to enhance the processes available to the Court when considering the ownership of taonga tuturu.

${ }^{80}$ The Maori Land Court is also empowered under s.12(2) to make an order prohibiting the sale of any artifact that was gifted according to Maori custom and usage.

${ }^{81}$ Any person who contravenes this requirement is liable to a fine not exceeding $\$ 1000$. However, under the POAB this maxima is proposed to be increased to $\$ 10,000$ for an individual, and $\$ 20,000$ in the case of a body corporate, for each taonga tuturu sold.

${ }^{82}$ It is also important to note that any building that has been identified as having 'heritage status' is also likely to require both a building consent under the BA and a resource consent under the RMA for any work proposed.

${ }^{83}$ Although the BA imposes a clear duty on territorial authorities to inform the NZHPT of applications for PIMs and building consents it does not entitle the Trust to make submissions on such applications and does not constitute a surrogate means of protection.

${ }^{84}$ Refer s.122 of the BA and the associated regulations that define 'moderate earthquake'. This definition is more comprehensive than its 1991 predecessor and now extends to include all buildings excluding small residential dwellings.

${ }^{85}$ Department of Housing and Building, Earthquake-Prone Building Provisions of the Building Act 2004: Policy

Guidance for Territorial Authorities, Department of Building and Housing, Wellington, 2005, p.10. 
${ }^{86}$ Further examples of related legislation include: Ngati Turangitukua Claims Settlement Act 1999, Pouakani Claims Settlement Act 2000, Te Uri O Hau Claims Settlement Act 2002, Ngati Ruanui Claims Settlement Act 2003, Ngati Tama Claims Settlement Act 2003, Ngati Awa Claims Settlement Act 2005 and Ngati Tuwheratoa (Bay of Plenty) Claims Settlement Act 2005.

${ }^{87}$ Statutory areas are defined by s.205 as 'areas, rivers, lakes, and wetlands described in Schedules 14-77, 100-104, and 108, the general description of which are indicated on the S.O. plans referred to in these schedules'. Included amongst the range of statutory areas identified in these schedules are, for example, Aoraki/Mount Cook, Lake Wanaka, Mata-au (Clutha River), Te Ana-au (Lake Te Anau), Okarito Lagoon, and the Waihola/Waipori Wetland.

${ }^{88}$ This is achieved through the inclusion of amending provisions to the RMA and HPA set out in ss.223-229 of the NTCSA.

${ }^{89}$ These include an investigation into historic and cultural heritage management undertaken by the Office of the Parliamentary Commissioner for the Environment in 1996 and a Ministerial review of historic heritage management initiated by Government in 1998. 